\title{
Development of an in vitro Plasmodium parasite killing assay for the evaluation of cell-mediated immune responses following vaccination with pre-erythrocytic malaria vaccine candidates
}

\author{
Carly M Bliss ${ }^{1 *}$, Ahmed M Salman ${ }^{1,2}$, Rhea J Longley', Shahid M Khan², Chris J Janse ${ }^{2}$, Adrian VS Hill', Katie J Ewer ${ }^{1}$
}

From Challanges in malaria research: Core science and innovation

Oxford, UK. 22-24 September 2014

\section{Background}

Vaccination against liver stage malaria antigens can induce $\mathrm{T}$ cell-mediated immunity to the disease [1]. A viral vector vaccination regime undergoing Phase $2 \mathrm{~b}$ clinical testing uses chimpanzee adenovirus 63 (ChAd63) and Modified Vaccinia virus Ankara (MVA) encoding liver stage antigen Thrombospondin-Related Adhesion Protein (TRAP) fused to a malaria multi-epitope string (ME). This regime induces high frequencies of antigen-specific $\mathrm{T}$ cells, providing $21 \%$ sterile protection and a delay to patent parasitaemia in a further $36 \%$ of vaccinees, following controlled human Plasmodium falciparum malaria infection (CHMI). Monofunctional IFNg-producing $\mathrm{CD}^{+} \mathrm{T}$ cells correlate with vaccine-induced protection but the associated protective mechanisms remain unidentified [2]. Developing standardized immunological and functional assays is a research-specific aim of the WHO's Malaria Vaccine Technology Roadmap, with emphasis on novel immunoassays for investigation of cellular products reflecting cellmediated malaria immunity [3]. Development of an in vitro parasite killing assay is underway, which quantifies cell-mediated killing of Plasmodium-infected human hepatocytes and investigates the underlying functional mechanisms. Additionally, the assay aims to compliment in vivo CHMI studies.

\section{Materials and methods}

Human hepatoma cell lines were infected with transgenic $P$. berghei sporozoites expressing TRAP from $P$. falciparum. Freshly separated peripheral blood mononuclear cells from

'Jenner Institute, Oxford, UK

Full list of author information is available at the end of the article
partial-HLA class I matched ChAd63.MVA ME-TRAP human vaccinees were enriched for $\mathrm{CD}^{+} \mathrm{T}$ cell populations. Following hepatocyte infection, enriched $\mathrm{CD} 8^{+}$ $T$ cells were added and incubated overnight. Level of infectivity was measured by flow cytometry through expression of GFP under a P. berghei promotor. TRAP-specific killing was calculated by subtraction of non-specific killing in wild type $P$. berghei-infected hepatocytes.

\section{Results}

Transgenic $P$. berghei sporozoites with full replacement of wild type TRAP infect human hepatoma cells at $>1 \%$ frequency. Preliminary results measure a 9.5-22\% TRAPspecific reduction of infected hepatocytes after addition of $\mathrm{CD}^{+} \mathrm{T}$ cells from ChAd63.MVA ME-TRAP vaccinees. Equivalently, TRAP-specific parasite killing was not detected following addition of $\mathrm{CD}^{+} \mathrm{T}$ cells from control volunteers. Conclusions Successful use of transgenic parasites and the preliminary results obtained provide proof of assay concept for this in vitro system. Further optimization will permit the investigation of cell-mediated parasite killing of $\mathrm{CD}^{+} \mathrm{T}$ cells from a larger number of vaccinees and extend to exploration of vaccine-induced mechanisms of protection.
Authors' details

'Jenner Institute, Oxford, UK. ' Leiden University Medical Centre, Leiden, The Netherlands.

Published: 22 September 2014

\section{References}

. Todryk SM, Walther M: Building better T-cell-inducing malaria vaccines. Immunology 2005, 115:163-169. 
2. Ewer $\mathrm{K}$, et al: Protective CD8+ T-cell immunity to human malaria induced by chimpanzee adenovirus-MVA immunisation. Nature communications 2013, 4.

3. Malaria Vaccine Technology Roadmap 2006. 2013 [http://www. malariavaccine. org/files/Malaria_Vaccine_TRM_Final_000.pdf], http://www. who.int/immunization/topics/malaria/vaccine_roadmap/TRM_update_nov13. pdf.

doi:10.1186/1475-2875-13-S1-P14

Cite this article as: Bliss et al.: Development of an in vitro Plasmodium parasite killing assay for the evaluation of cell-mediated immune responses following vaccination with pre-erythrocytic malaria vaccine candidates. Malaria Journal 2014 13(Suppl 1):P14.

Submit your next manuscript to BioMed Central and take full advantage of:

- Convenient online submission

- Thorough peer review

- No space constraints or color figure charges

- Immediate publication on acceptance

- Inclusion in PubMed, CAS, Scopus and Google Scholar

- Research which is freely available for redistribution

Submit your manuscript at www.biomedcentral.com/submit
C) Biomed Central 